\title{
Potent antioxidant peptides derived from honey major protein enhance tolerance of eukaryotic cells toward oxidative stress
}

\author{
Hisham R. Ibrahim iD, Fukiko Nanbu and Takeshi Miyata
}

\begin{abstract}
Honey is known for its medicinal benefits and receiving renewed attention as natural medicine. Studies on health benefits of honey attributed its antioxidant activity to phenolic compounds, but the contribution of proteins and peptides to the antioxidant activity of honey is lacking. The aim of this study was to explore the contribution of proteins and peptides to the antioxidant activity of honey, which remained obscure for decades.

Total honey proteins (THP) were isolated by dialysis method and hydrolyzed through simulated gastrointestinal digestion. The hydrolysates were fractionated using size-exclusion chromatography. The antioxidant activity was determined by using superoxide radical-scavenging, DPPH reduction and intracellular ROS assays.

THP was shown to exhibit superoxide-scavenging activity but its pepsin-hydrolysate

(HP-p) showed superior scavenging activity. The HP-p produced five peptide fractions (P1 P5) when fractionated on Sephacryl S-100 size-exclusion column. The five fractions showed superoxide-scavenging activities and DPPH reducing activities, whereas the slow-eluting peptide fractions (P3 and P4) were the most potent. MALDI-TOF/MS analysis identified a pentapeptide (TSNTF) as the dominant peptide in the active fractions P3 and P4. Human colonic epithelial cells treated with P3 and P4 peptides exhibited lower intracellular ROS, when oxidative stress was induced by $\mathrm{H}_{2} \mathrm{O}_{2}$ or diethyl maleate (DEM), indicating strong tolerance to oxidative stress. The viabilities of human cells or yeast cells were largely decreases under oxidative stress, but treated cells with P3 and P4 showed higher viability compared with the untreated cells. The results are the first to describe a novel antioxidant peptide from honey that confer ex vivo anti-oxidative function within a complicated milieu of eukaryotic cells and pave the way for its potential as nutraceutical or therapeutic peptide for risk-reduction of oxidative-stress and related diseases.
\end{abstract}

Keywords: Honey, Proteins, Biopeptides, Antioxidant, Intracellular oxidative stress

\section{Introduction}

Honey has been used to treat a variety of ailments through topical application, but only recently have the antiseptic and antioxidant properties of honey been reported (Masalha et al. 2018). Honey is a mixture of sugars, proteins, polyphenols, vitamins, minerals and free amino acids. The antioxidant activity of honey is an important aspect correlating with its anti-inflammatory and

\footnotetext{
*Correspondence: hishamri@chem.agri.kagoshima-u.ac.jp; hishamri@agri.kagoshima-u.ac.jp; k2504042@kadai.jp Department of Biochemistry and Biotechnology, Faculty of Agriculture, Kagoshima University, Kagoshima 890-0065, Japan
}

wound healing actions (Jerkovic et al. 2015; Masalha et al. 2018). Honey has been found to have antioxidant activity, measured as the ability to remove free radicals involved in infection-induced inflammation (Almasaudi et al. 2017; Kumul et al. 2015) and to reduce the damage caused to the colon in colitis in rats (Nooh and NourEldien 2016; Teobaldi et al. 2018).

Proteins make up about 0.2 to $0.5 \%$ of honey, but the biological activities of honey proteins are yet largely unknown. Previous studies showed that honey proteins are mainly the major royal jelly proteins MRJP (Chua et al. 2015). The MRJP family is composed of nine members,

(c) The Author(s). 2021 Open Access This article is licensed under a Creative Commons Attribution 4.0 International License, which permits use, sharing, adaptation, distribution and reproduction in any medium or format, as long as you give appropriate credit to the original author(s) and the source, provide a link to the Creative Commons licence, and indicate if changes were made. The images or other third party material in this article are included in the article's Creative Commons licence, unless indicated otherwise in a credit line to the material. If material is not included in the article's Creative Commons licence and your intended use is not permitted by statutory regulation or exceeds the permitted use, you will need to obtain permission directly from the copyright holder. To view a copy of this licence, visit http://creativecommons.org/licenses/by/4.0/. 
MRJP 1 to 9, sharing primary structures but differ in their molecular weights (Ramanathan et al. 2018). A MALDI-TOF-MS study identified MRJP1 as the most abundant protein in honey bee product (Won et al. 2008). In a recent proteomic study of honey, five major proteins were identified in any type of honey, belonging to the family of MRJP 1-5 (Di Girolamo et al. 2012). Structural characterization of honey proteins have recently been explored (Chua et al. 2013; Chua et al. 2015), but their contribution in the biological function of honey remains obscure.

Although some of the antioxidant activity of honey has been contributed from phenolic compounds (Brudzynski and Maldonado-Alvarez 2018; Masalha et al. 2018), studies exploring the antioxidant activity of honey proteins and peptides are lacking. Thus, it is important to identify the bioactive peptides of honey proteins, which may be responsible for the antioxidant activity of honey. This study is aimed to explore the antioxidant biopeptides in the honey proteins through gastrointestinal digestion simulation. Because many diseases are associated with the generation of superoxide radicals, we employed xanthine-xanthine oxidase-system that generates superoxide radicals to explore the superoxide scavenging potential of honey proteins and peptides. We also took advantage of the redox active human colonic epithelial cells (HCT-116) and yeast cells (YNN27 Saccharomyces cerevisiae) to evaluate attenuation of the intracellular oxidative stress by honey proteins and peptides.

\section{Materials and methods}

\section{Materials}

Pure Renge honey was purchased from Takano Apiary (Kagoshima, Japan). Xanthine (X), xanthine oxidase (XOD), nitroblue tetrazolium (NBT), 2',7'-dichlorodihydrofluorescein diacetate (DCFH-DA), 2,2-Diphenyl- 1-picrylhydrazyl $(\mathrm{DPPH})$, pepsin, trypsin and $\alpha$-chymotrypsin were from Sigma-Aldrich (Tokyo, Japan). Diethyl maleate (DEM) and hydrogen peroxide $\left(\mathrm{H}_{2} \mathrm{O}_{2}\right)$ were from Nacalai tesque (Tokyo, Japan). Alpha-cyano-4-hydroxy-cinnamic acid $(\alpha-$ HCCA) was from Bruker Daltonik (Bremen, Germany). McCoy 5a medium was from ICN (Invitrogen, Japan). Sephacryl S-100 was product of Amersham-Pharmacia Biotech (Tokyo, Japan).

\section{Gastrointestinal simulated digestion of crude proteins}

Sugar, vitamins, minerals, polyphenols and free amino acids were removed from raw honey by dialysis against $\mathrm{dH}_{2} \mathrm{O}$ using 1000 MWCO tubes as described earlier (Chua et al. 2015). The retentate was lyophilized and referred to as crude total honey proteins (THP). The proximate protein content of THP was $94 \%$, as assessed by Bradford proteins assay (Bio-Rad, Japan) using bovine serum albumin as standard. The THP in $\mathrm{HCl}$ solution (pH 2.0 or 4.0) was mixed with pepsin to give pepsin-toprotein weight ratio of 1:30. Upon incubation for $2 \mathrm{~h}$ at $37^{\circ} \mathrm{C}$, reactions were heated at $85^{\circ} \mathrm{C}$ for $5 \mathrm{~min}$ to inactivate pepsin and centrifuged at $3000 \times$ g for $10 \mathrm{~min}$. The supernatants were adjusted to $\mathrm{pH} 7.0$ then lyophilized, referred to as pepsin digested-HP at $\mathrm{pH} 2$ (HP-p2) and pepsin digested-HP at $\mathrm{pH} 4$ (HP-p4). Digests were dissolved in $50 \mathrm{mmol} / \mathrm{L} \mathrm{Na-phosphate} \mathrm{buffer} \mathrm{(pH} \mathrm{7.5)} \mathrm{then}$ trypsin or $\alpha$-chymotrypsin was added individually or together at final enzyme-to-substrate weight ratio of $1 /$ 100. After incubation for $2 \mathrm{~h}$ at $37^{\circ} \mathrm{C}$ reactions were heat inactivated as above and freeze dried. Reactions predigested with pepsin at $\mathrm{pH} 2.0$ were referred to as HPp2T, HPp2- $\alpha$ and HPp2- $\alpha / \mathrm{T}$ when digested with trypsin, $\alpha$-chymotrypsin and both enzymes, respectively. Reactions predigested with pepsin at $\mathrm{pH} 4.0$ were referred to as HPp4-T, HPp4- $\alpha$ and HPp4- $\alpha / \mathrm{T}$ when digested with trypsin, $\alpha$-chymotrypsin and both enzymes, respectively.

\section{Isolation of the active peptides}

The most active hydrolysate was fractionated using Sephacryl S-100 column, eluted with $12.5 \mathrm{mmol} / \mathrm{L}$ pyridine-acetate buffer ( $\mathrm{pH}$ 5.5). Peptide fractions were collected, vacuum dried and re-suspended in Milli-Q water. The profile and degree of protein hydrolysis were evaluated by SDS-PAGE under reducing condition on 4-15\% acrylamide gels, according to standard protocols (Laemmli 1970). Protein bands were visualized with Coomassie Brilliant Blue R-250 (CBB). Gel was detained with methanol:acetic acid: water $(2: 1: 7 \mathrm{vol} / \mathrm{vol})$ solution.

\section{Antioxidant activity}

The antioxidant activity was assessed by two methods: (1) superoxide radical-scavenging assay, and (2) DPPH reduction assay. The superoxide generated by xanthine/ xanthine oxidase (X/XOD) system in the presence of NBT as a probe was employed to assess superoxidescavenging activity (Ibrahim et al. 2018). The scavenging capacity is expressed as the degree of NBT reduction by superoxide and absorbance measured at $562 \mathrm{~nm}$. A reaction mixture $(100 \mu \mathrm{L})$ containing $41.4 \mu \mathrm{mol} / \mathrm{L}$ NBT, 5 $\mathrm{mU}$ xanthine and protein or peptide samples $(100 \mu \mathrm{g} /$ $\mathrm{mL}$ ) in phosphate buffer ( $\mathrm{pH} 8.0)$ in a 96-well plate was mixed with $100 \mu \mathrm{L}$ of $5 \mathrm{mU}$ XOD. Control (Ctrl) contained water instead of protein sample. The flux of superoxide anion was monitored at $562 \mathrm{~nm}\left(37^{\circ} \mathrm{C}\right)$ kinetically for 20 min using Ultrospec Biotrak II microplate reader (Amersham Biosciences, Uppsala, Sweden). The results were expressed as the rate of absorbance change, by subtracting the reading at 0 time from the subsequent readings; $(\partial \mathrm{Abs})=\mathrm{Abs}$ (given time) $-\mathrm{Abs}(0$ time). Results are representative of two independent experiments in three wells per sample. 
DPPH reduction was assessed by using the TLC-dot assay, as described earlier (Ahmed et al. 2015). Briefly, protein samples were spotted on a thin layer chromatography (TLC) sheet. In control reaction (Ctrl) water was spotted instead of protein. The sheets were air-dried and sprayed with DPPH solution $(2 \mathrm{mmol} / \mathrm{L})$. The sheets were photographed after 15 min incubation in a dark box. Spots containing radical-scavenger will appear as white spot in a purple background. Control spot without scavenger (buffer only) will remain purple as shown in Fig. 3a top panel (Ctrl).

\section{Human epithelial cells model for oxidative stress}

The ability of antioxidant peptides to protect eukaryotic cells against oxidative stress was assessed by inducing oxidative stress with $\mathrm{H}_{2} \mathrm{O}_{2}$ or DEM (highly oxidative stress inducer). For human epithelial cells (HCT-116), cells were suspended in McCoy's 5a medium to $10^{5}$ cells $/ \mathrm{mL}$ in 96 -well black plate. A $100 \mu \mathrm{L}$ containing peptide $(200 \mu \mathrm{g} / \mathrm{mL})$ and an oxidizing agent $(1 \mathrm{mmol} / \mathrm{L}$ $\mathrm{H}_{2} \mathrm{O}_{2}$ or $2 \mathrm{mmol} / \mathrm{L}$ of DEM) was added to $100 \mu \mathrm{L}$ cells suspension and incubated for $1 \mathrm{~h}$ at $37^{\circ} \mathrm{C}$ under $5 \%$ $\mathrm{CO}_{2}$. Cells were pelleted at $2000 \times \mathrm{g}$ for $5 \mathrm{~min}$ and fluorescent redox probe DCFH-DA $(1 \mathrm{mmol} / \mathrm{L})$ in $100 \mu \mathrm{L}$ PBS buffer ( $\mathrm{pH} 7.2$ ) was added then incubated for 30 min at $37{ }^{\circ} \mathrm{C}$. Emission was measured at $538 \mathrm{~nm}$ upon excitation at $485 \mathrm{~nm}$ using Infinite M200 FA fluorescence microplate reader (Tecan, Japan). Data are presented as mean \pm standard deviation as percentage of viability. The rest of cells were used for fluorescence microscopic observation. Cells were washed two times with cold PBS and fixed with $2 \%$ paraformaldehyde in PBS, to preserve the chemical and physical characteristics of cells. Cell fluorescence was observed with Keyence BZ-9000 fluorescence microscope (Eurotek Inc., NJ, USA), under antifade reagent. A portion of treated cells was used to measure viability with trypan blue using TC10 automated cell counter (Bio-Rad).

\section{Yeast cells model for oxidative stress}

Saccharomyces cerevisiae (YNN27) cells in yeast extract peptone dextrose (YPD) broth at $10^{4} \mathrm{CFU} / \mathrm{mL}$ were incubated with peptides $(200 \mu \mathrm{g} / \mathrm{mL})$ at $28^{\circ} \mathrm{C}$ for $1 \mathrm{~h}$. Hydrogen peroxide $\left(\mathrm{H}_{2} \mathrm{O}_{2}\right)$ was added $(2 \mathrm{mmol} / \mathrm{L})$, and the incubation was extended for $48 \mathrm{~h}$. A $10-\mu \mathrm{L}$ portion of serially diluted cultures in $2 \mathrm{mmol} / \mathrm{L}_{2} \mathrm{O}_{2}$ was spotted on YPD agar plates containing $2 \mathrm{mmol} / \mathrm{L} \mathrm{H}_{2} \mathrm{O}_{2}$. Plates were incubated for $72 \mathrm{~h}$ at $28^{\circ} \mathrm{C}$ and the colony forming units of yeast was estimated. Data are presented as mean \pm standard deviation as percentage of survival.

\section{MALDI-TOF-MS analysis}

Peptide solutions were spotted on a polished steel target plate, then equal volume of MALDI matrix $(10 \mathrm{mg} / \mathrm{mL}$ of $\alpha$-HCCA in $50 \%$ acetonitrile- $2.5 \%$ trifluoroacetic acid) was added and allowed to air-dry. MALDI-TOF/MS analyses were performed with Autoflex Speed mass spectrometer (Bruker Daltonik GmbH, Germany), in positive reflector mode in the mass range of $1000 \sim 3200$ Da. Calibration was done by using peptides calibration standard I, and data analysis were accomplished with flexAnalysis tools (Bruker Daltonik). The sequences of peptides were identified by subjecting the major precursor ions in each peak to MS/MS analysis, using automated application to MASCOT and SEQUEST database.

Data obtained in the study were analyzed statistically using ANOVA by Excel's data analysis tools.

\section{Results}

\section{Digestion of honey proteins}

The total honey proteins (THP) were isolated through removal of sugars, amino acids, minerals and vitamins by dialysis. THP was hydrolyzed with pepsin under two $\mathrm{pH}$ conditions ( $\mathrm{pH} 2.0$ and 4.0) followed by trypsin or $\alpha$ chymotrypsin or both enzymes. Proteins and hydrolysates were analyzed by SDS-PAGE under reducing condition (Fig. 1), intact THP (THP, none) exhibited 3 major protein bands at $68.5,63.2,50.7 \mathrm{kDa}$ (bands 2,3 and 4 , respectively) and a less dense band at $74.1 \mathrm{kDa}$ (band 1). Digestion of THP with trypsin (T), $\alpha$-chymotrypsin $(\alpha)$ or both proteases $(\mathrm{T} / \alpha)$ resulted in partial digestion of protein bands with the appearance of low molecular weight bands. Pepsin at pH 2.0 (HP-p2, none) produced low mass peptides with smearing at the low zone of the gel. Digestion of HP-p2 with trypsin (T) or $\alpha$-chymotrypsin $(\alpha)$ or both proteases $(\mathrm{T} / \alpha)$ converted proteins into very small peptides accompanied with a peptide band at $24 \mathrm{kDa}$ with trypsin and at $17 \mathrm{kDa}$ with $\alpha$-chymotrypsin ( $\alpha$ or T/ $\alpha$ ). Apparently, the band at $24 \mathrm{kDa}$ is trypsin and that at $17 \mathrm{kDa}$ derived from autolysis of $\alpha$-chymotrypsin (Hofstee 1965; Kumar and Hein 1970). Pepsin digest at $\mathrm{pH} 4.0$ (HP-p4) or its post treatment with trypsin $(\mathrm{T})$ or $\alpha$-chymotrypsin $(\alpha$ or $\mathrm{T} / \alpha)$ resulted in less efficient proteolysis of proteins than that at $\mathrm{pH}$ 2.0. It is, thus, evident that pepsin at $\mathrm{pH} 2.0$ is the most effective protease to converted THP into small peptides.

\section{Antioxidant activity}

The intact THP and pepsin hydrolysates (HP-p2 and HP-p4) were assessed for ability to scavenge superoxide radicals and reduce the chemical DPPH radical (Fig. 2). The THP showed remarkable decrease in the optical density (A562) of the blue diformazan, demonstrating superoxide-scavenging activity (Fig. 2a). Digestion of THP with trypsin (THP-T) or $\alpha$-chymotrypsin (THP- $\alpha$ ) or both proteases (THP-T/ $\alpha$ ) resulted in loss of 


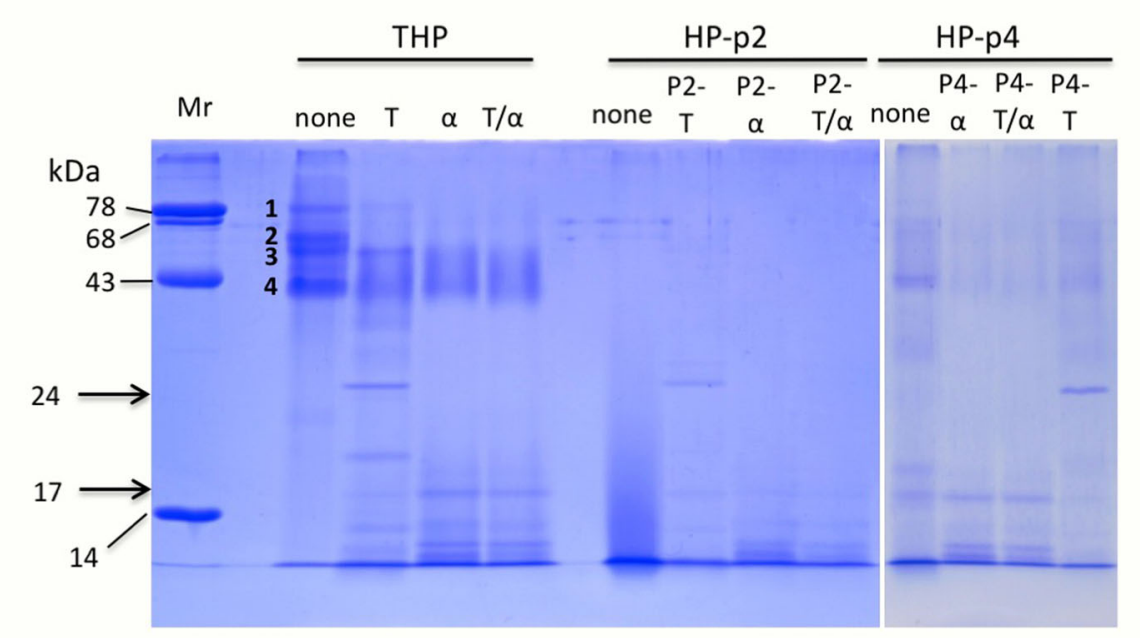

Fig. 1 SDS-PAGE of THP subjected to gastrointestinal digestion without pepsin (THP) or with peptic digestion at pH 2.0 (HP-p2) and pH 4.0 (HPp4) on reducing SDS 15\% polyacrylamide gel. Mr., molecular weight marker; none, intact THP or pepsin alone digests; $\mathrm{a}_{1} \mathrm{~T} / \mathrm{a}$ and T, THP or peptic hydrolysates digested with a-chymotrypsin alone, a-chymotrypsin with trypsin or trypsin alone, respectively

superoxide scavenging activity (Fig. 2a). Pepsin hydrolysates, HP-p2 or HP-p4, exhibited superior superoxide scavenging activities (Fig. $2 \mathrm{~b}$ and $\mathrm{c}$, respectively). Treatment of HP-p2 with $\alpha$-chymotrypsin (HPp2- $\alpha$ ) showed moderate superoxide-scavenging activity (Fig. 2b). Post proteases treatment of HP-p4 resulted in loss of the scavenging activity (Fig. 2c). The ability to reduce DPPH was conducted to delineate whether the antioxidant activity is specific to oxygen radical or it is the reducing capacity of the peptides (Fig. 2, top panels). THP and its digests $(T, \alpha, T / \alpha)$ showed weak DPPH-reducing capacity (Fig. 2a). However, peptic hydrolysate HP-p2 and its post protease digests (HP-p2; T, $\alpha, \mathrm{T} / \alpha)$ exhibited significant DPPH reducing capacity, as intense white spots are produced (Fig. 2b). Although HP-p4 (none) showed $\mathrm{DPPH}$ reducing activity, its post protease digests $(\mathrm{T}, \alpha$, $\mathrm{T} / \alpha$ ) resulted in almost loss of the activity (Fig. $2 \mathrm{c}$ ). The results indicate that HP-p2 possess peptides potently

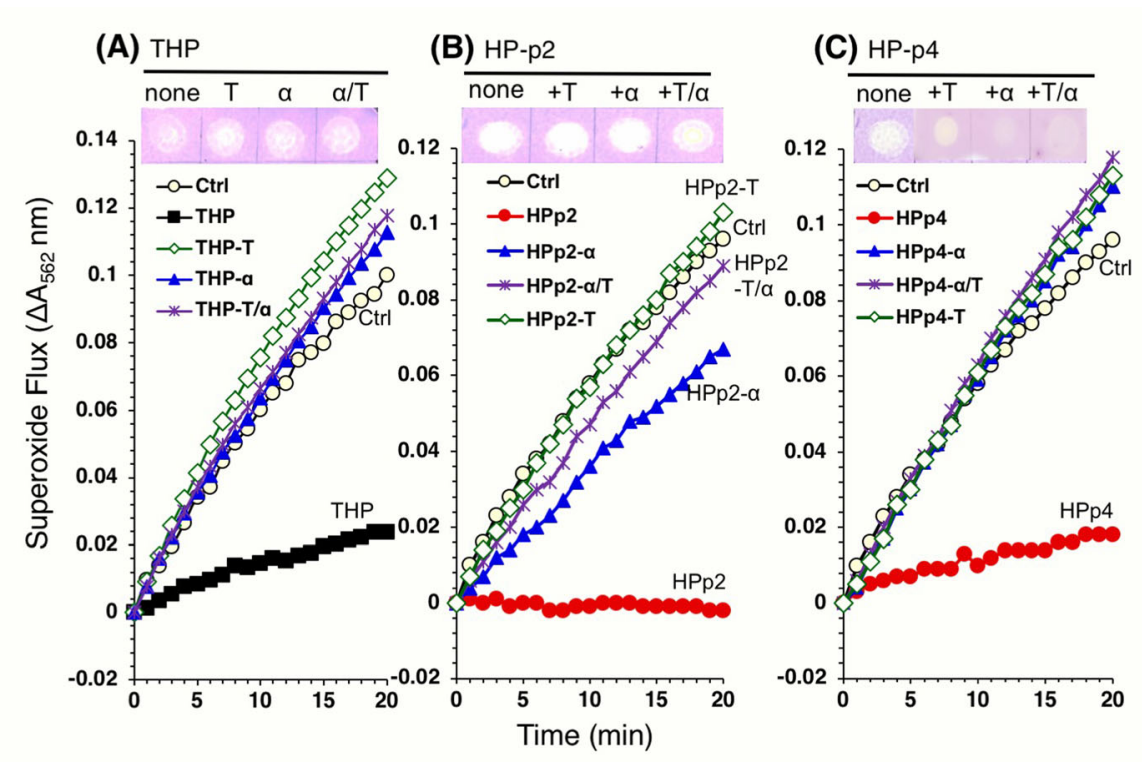

Fig. 2 Antioxidant activities of THP and its hydrolysates. The superoxide-scavenging activity was assessed at $55 \mu \mathrm{g} / \mathrm{mL}$ of $\mathbf{a}$ intact THP or $\mathbf{b}$ its peptic hydrolysates at pH $2.0(\mathrm{HP}-\mathrm{p} 2)$ or $\mathbf{c} \mathrm{pH} 4.0(\mathrm{HP}-\mathrm{p} 4)$ upon digestion with trypsin $(+\mathrm{T})$, a-chymotrypsin $(+\mathrm{a})$ or both $(+\mathrm{T} / \mathrm{a})$. Ctrl, reaction in the absence of protein. The corresponding DPPH reduction activities are shown on the top of each panel 
able to scavenge oxygen superoxide anions and reduce the chemical radical DPPH.

\section{Fractionation of honey peptides}

The peptic hydrolysate HP-p2 was separated into 5 peptide fractions (P1 to P5) on size-exclusion column, Sephacryl S-100 column (Fig. 3a). As shown in Fig. 3a inset, fractions $\mathrm{P} 3$ and $\mathrm{P} 4$ exhibited strong DPPH reduction activities while the parent hydrolysate (HP-p2) and P5 showed moderate activities. The fast-eluting fractions (P1 and P2) showed weak activities. The HP-p2 and all fractions showed strong superoxide-scavenging activities whereas P3 and P4 showed significantly stronger scavenging activities (Fig. 3b). The results demonstrate the superiority of peptides in fractions $\mathrm{P} 3$ and $\mathrm{P} 4$ as potent antioxidants than the other peptide fractions.

\section{Tolerance of human epithelial cells against oxidative stress}

The ability of P3 and P4 to efficiently scavenge superoxide anions and reduce DPPH radical led us to anticipate that these peptides could protect eukaryotic cells against oxidative stress. The oxidative stress of human colon epithelial carcinoma cells (HCT-116) was induced by $\mathrm{H}_{2} \mathrm{O}_{2}$ or DEM. The non-fluorescent DCFHDA was used to penetrate the cells, deacetylated by cellular esterase then react with ROS to metabolize into fluorescent DCF that can be detected by fluorescence spectrophotometry at $538 \mathrm{~nm}$ emission (Fig. 4a and b) and fluorescence microscope (Fig. 5). As shown in Fig. 4, treatment of HCT-116 cells with $\mathrm{H}_{2} \mathrm{O}_{2}$ (A, Mock) or
DEM (B, Mock) produced high intra-cellular ROS levels. Under $\mathrm{H}_{2} \mathrm{O}_{2}$-induced oxidative stress, HCT-116 cells treated with THP, HP-p2, P3 or P4 exhibited lower intracellular ROS levels compared to mock-treated cells whereas the treatment with HP-p2 or P3 showed the lowest ROS levels, $28 \%$ of mock (Fig. 4a). Under DEMinduced oxidative stress, treatment of HCT-116 cells with DEM produced intra-cellular ROS levels 5 times higher than under $\mathrm{H}_{2} \mathrm{O}_{2}$ (Fig. 4b, Mock). ROS levels in the P3 and P4 treated groups decreased significantly (Fig. 4b). Interestingly, fluorescence microscopic observation of $\mathrm{HCT}-116$ cells, oxidatively challenged by $\mathrm{H}_{2} \mathrm{O}_{2}$ or DEM, treated with P3 or P4 resulted in total abolishment of the DCF fluorescence (Fig. 5). The image shows a significant decrease in fluorescence in HCT-116 cells when treated with P3 or P4 that contains mainly the TSNTF peptide, almost with the same intensity as noninduced control cells, shown in supplementary materials (Fig. S1). The results demonstrate that the peptides in P3 and P4 can induce tolerance to oxidative damage of human cells.

\section{Survival of human epithelial and yeast cells under oxidative stress}

DEM is a highly cytotoxic oxidative stress inducer with specificity to deplete intracellular glutathione (GSH). Quantitation of cells survival of the DEM-induced HCT116 indicated severe death of mock treated cells $(22 \%$ survival) while cells pretreated with P3 and P4 retained high viability, 57 and $89 \%$, respectively (Fig. 6a). It is likely that peptides in P3 and P4 act through modulation

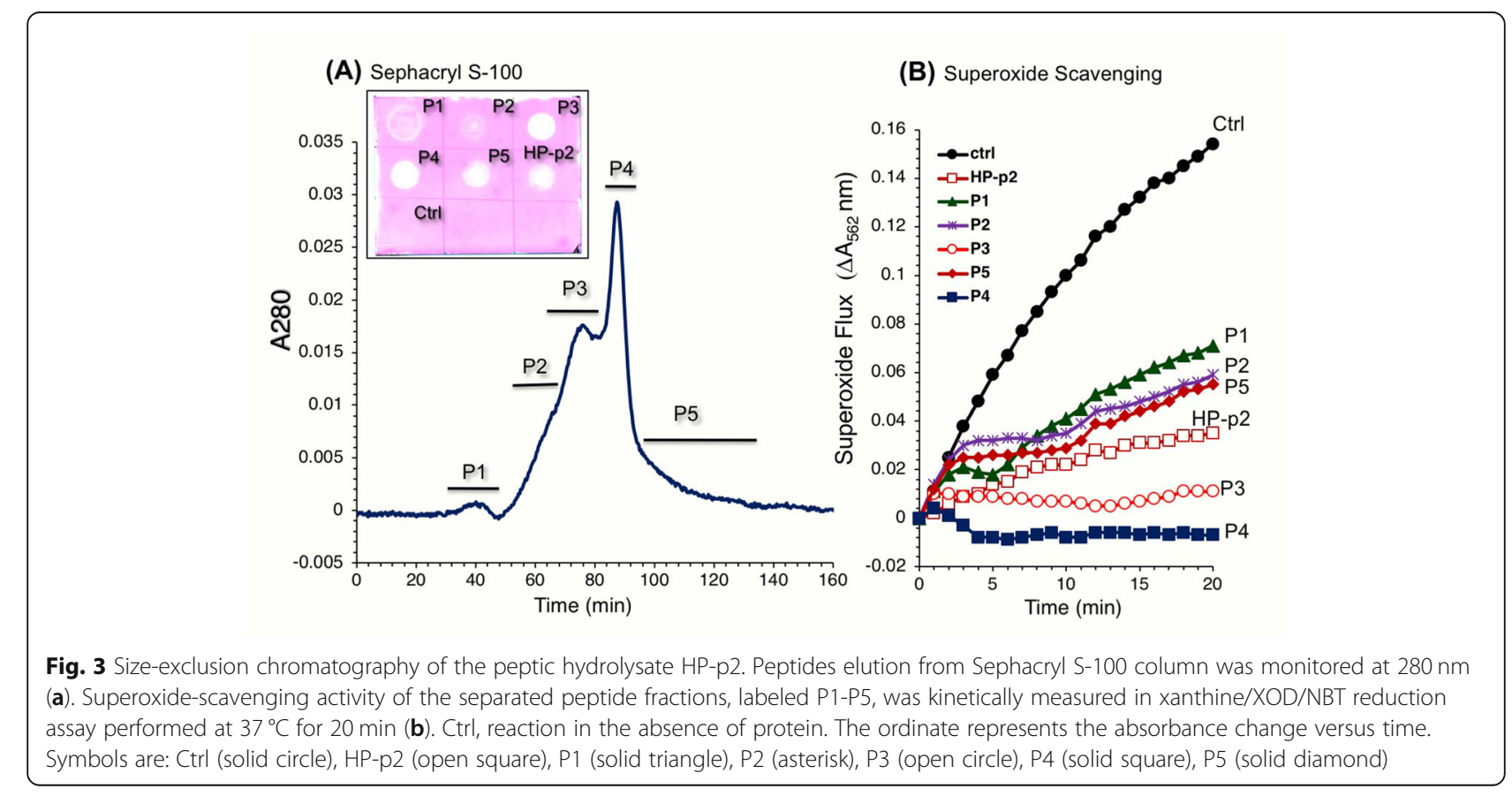




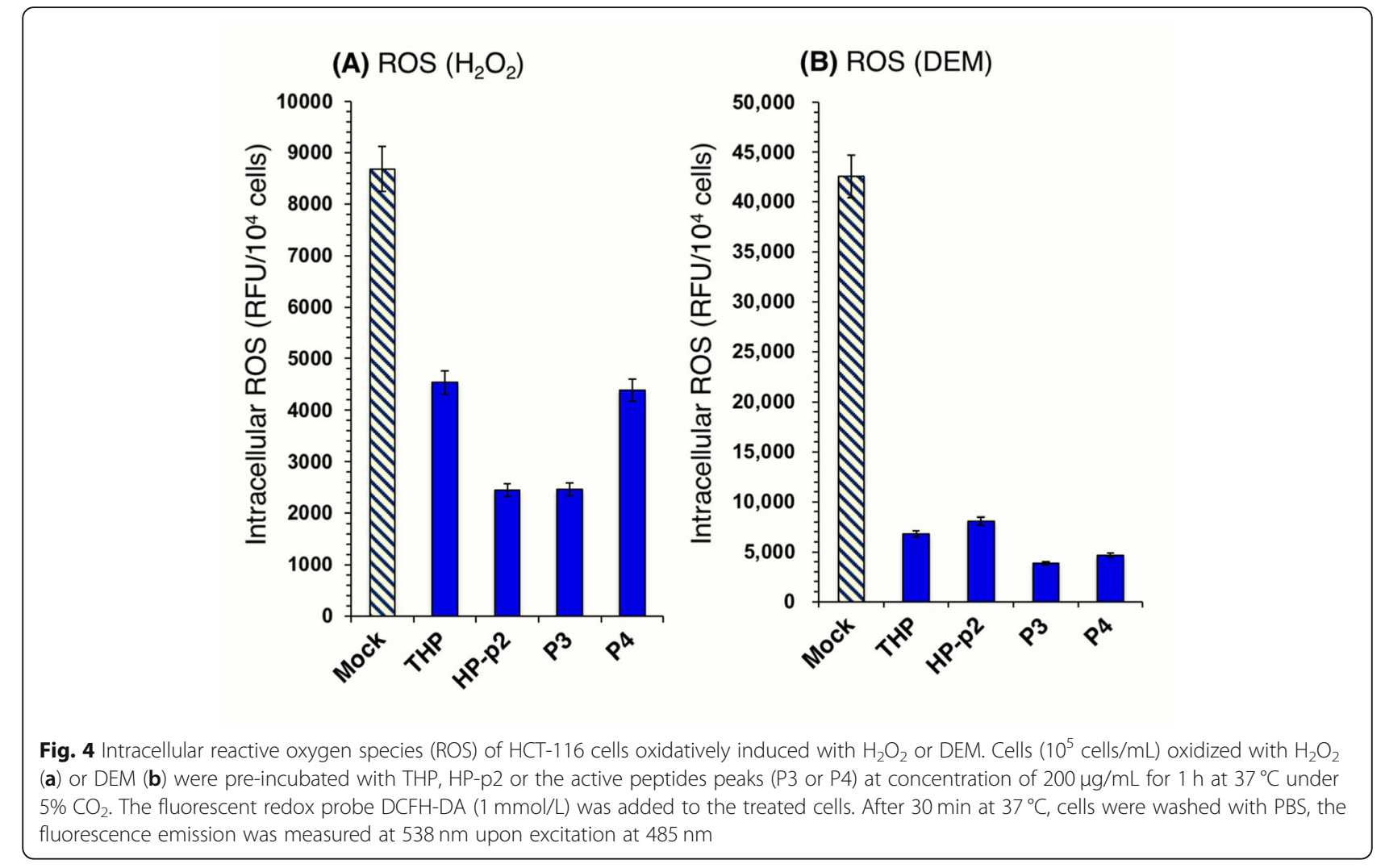

\section{(A) $\mathrm{H}_{2} \mathrm{O}_{2}$}
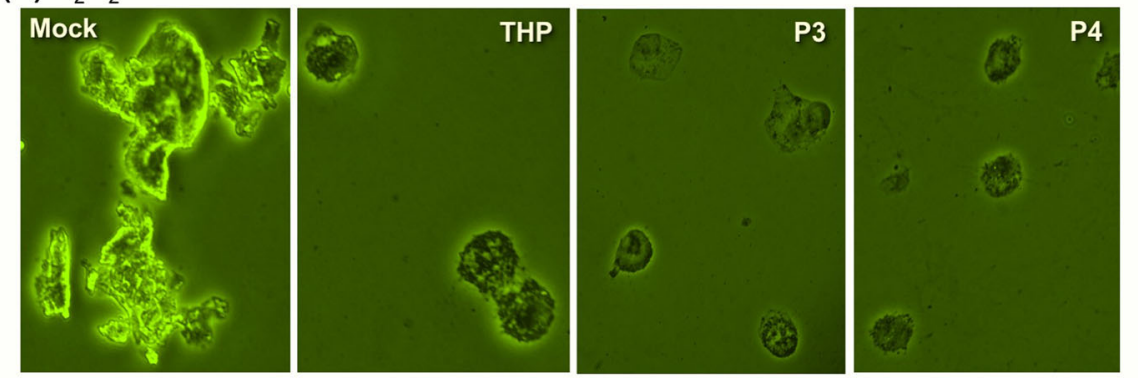

(B) DEM
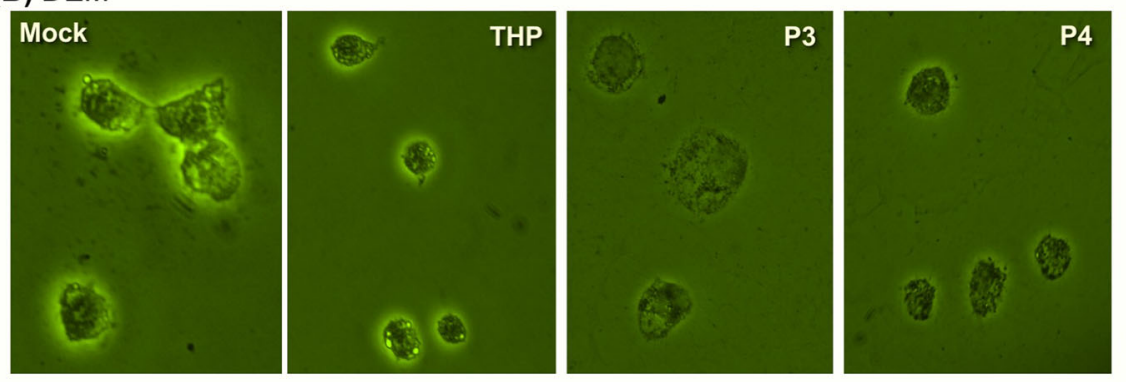

Fig. 5 Fluorescent ex vivo imaging of ROS in HCT-116 cells oxidized with $\mathrm{H}_{2} \mathrm{O}_{2}$ or DEM. Cells $\left(10^{5}\right.$ cells/L) were treated as in Fig. 4 and fixed with 2\% paraformaldehyde in PBS and observed with Keyence BZ-9000 fluorescence microscope under antifade reagent. The non-fluorescent DCFHDA is oxidized by ROS into DCF, which irradiates green/yellow fluorescence into and around the stressed cells 
of the cellular redox environment to a more reducing condition by direct regeneration of GSH or activation of GSH reductases. The ability of yeast cells to tolerate $\mathrm{H}_{2} \mathrm{O}_{2}$-induced oxidative stress was also assessed by spotting the serially diluted cells on agar plates containing 2 $\mathrm{mM}$ of $\mathrm{H}_{2} \mathrm{O}_{2}$ then determining the colony forming units (cfu) after 2 days incubation. The treated yeast cells with THP, HP-p2, P3 or P4 showed higher viabilities than the mock-treated yeast cells (Fig. 6b). However, yeast cells treated with P3 showed 100\% viability compared to $57 \%$ viability of the mock-treated cells. The results indicate that peptides in P3 act as defense molecules against intracellular oxidative damage.

\section{Peptides identification}

Peptide in P3 and P4 were analyzed by MALDI-TOF/ MS. The P3 contained a major pentapeptide (TSNTF) with mass of 568.17 and two minor peptides with masses of 524.20 and $871.45 \mathrm{Da}$ (Table 1 and Fig. S2). The P4 contained similar peptide patterns with the major pentapeptide (TSNTF), but lacking the $871.45 \mathrm{Da}$ peptide. The overlap of peptide sequences in P3 and P4 may be due to the close proximity of peaks in Fig. 3a. All peptides were derived from the MRJP1 of honey. The major peptide (TSNTF) in P3 and P4 corresponds to the residues 208-212 of MRJP1 (Table 1 and Fig. S3). The
TSNTF peptide is a conserved sequence not only in MRJP1, but also in MRJP 2, MRJP 3 and MRJP 5 (Albert et al. 1999; Ramanathan et al. 2018). The sequence of the TSNTF peptide appears resistance to tryptic digestion but HP-p2-T lost superoxide scavenging activity (Fig. 2b). The peptic hydrolysate was heated at $\mathrm{pH} 2.0$ to inactivate the enzyme, while heated at $\mathrm{pH} 7.0$ upon trypsin digestion. Most likely heating at neutral $\mathrm{pH}$ resulted in extensive aggregation leading to lose of the peptide in the precipitate. The sequence TSNTF is unique that shares no similarity to any bio-active peptides, suggesting that the peptide constitute a novel class of antioxidant peptide.

\section{Discussion}

Honey has been used as a food and a medicine since the ancient times, particularly for its antioxidant and antimicrobial properties (Ahmed et al. 2018; Shenoy et al. 2012). Most studies so far attributed the antioxidant activity of honey to its phenolic compounds (Combarros-Fuertes et al. 2019). But information about the contribution of honey proteins and their peptides in its antioxidant activity is lacking. In this study, it was demonstrated that honey proteins (THP) showed moderate superoxide scavenging activity (Fig. 2a) and their peptic hydrolysates (HP-p2) showed superior antioxidant

\section{(A) HCT-116 Viability}

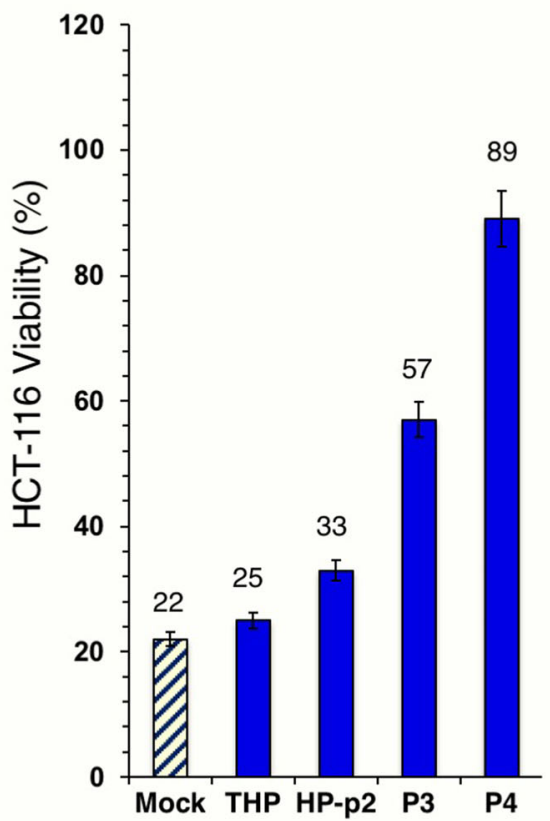

(B) Yeast Viability

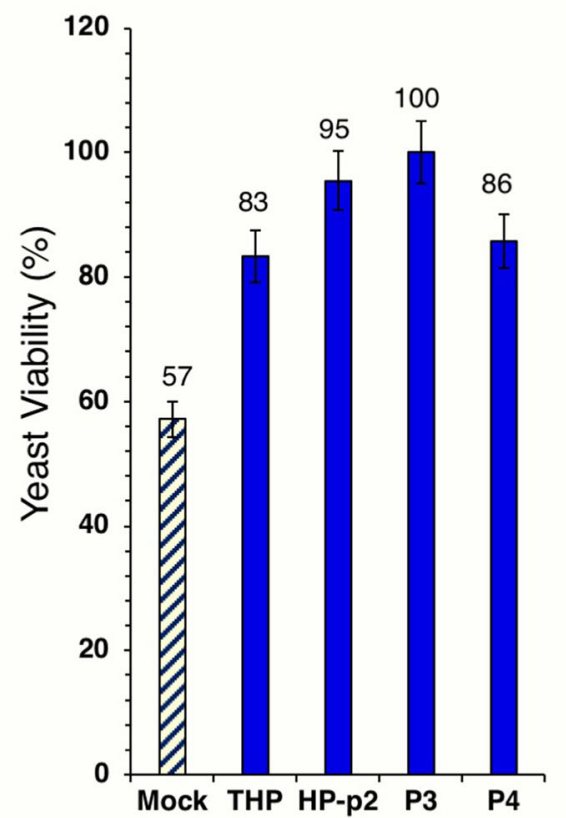

Fig. 6 Viability of HCT-116 (a) and yeast (b) cells oxidized with DEM or $\mathrm{H}_{2} \mathrm{O}_{2}$, respectively. Cell viability of DEM-treated HCT-116 was measured using trypan blue exclusion assay (a). Viability of $\mathrm{H}_{2} \mathrm{O}_{2}$-treated yeast cells was measured by colony counting on YPD agar plates (b). Viability was represented as survival percentage to the non-induced cells 
Table 1 Peptides identified by MALDI-TOF/MS in the Sephacryl-S100 active peaks of HP-p2 hydrolysates

\begin{tabular}{llllll}
\hline Sephacry-S100 Peak & TOF-MS (Da) & Calculated mass (Da) & Sequence $^{\text {a }}$ & Relative Intensity (\%) $^{\text {Protein Identity (fragment) }}$ \\
\hline P3 & 524.20 & 526.31 & HRTL & 38.86 & MRJP1 (f 314-317) \\
& 568.17 & 568.25 & TSNTF & $\mathbf{1 0 0 . 0 0}$ & MRJP1 (f 208-212) \\
& 871.45 & 867.40 & KMVNNDF & 12.26 & MRJP1 (f 368-374) \\
P4 & 524.20 & 526.31 & HRTL & 36.53 & MRJP1 (f 314-317) \\
& 568.17 & 568.25 & TSNTF & $\mathbf{1 0 0 . 0 0}$ & MRJP1 (f 208-212) \\
\hline
\end{tabular}

a Peptide sequences were identified by manual interpretation of the ion series in MALDI-TOF/MS. The major peptide in peaks are shown in bold letters

activity (Fig. 2b and c). The peptide fractions P3 and P4 eluted from size exclusion chromatography of HP-p2 (Fig. 3a) were able to completely scavenge superoxide generated in XOD coupling system (Fig. 3b), and greatly reduced the intracellular reactive oxygen species (ROS) in oxidatively stressed cells (Figs. 4 and 5). When HCT116 cells were oxidatively stressed with DEM, P4 not only reduced the intracellular ROS species, but also was able to potently rescue the viability from $22 \%$ (mock) to $89 \%$ (Fig. 6a). We have also evaluated the viability of yeast cells and it was found that P3 and P4 rescue 100 and $86 \%$ yeast cells, respectively, when oxidativelyinduced with peroxide (Fig. 6b).

Diethyl maleate (DEM) is known to severely induce oxidative stress in eukaryotic cells by depleting intracellular glutathione (Geter et al. 2012). This suggests that the ability of the peptide (mainly TSNTF peptide) to enhance tolerance against oxidative stress in human cells would be attributed to the modulation of antioxidant response. The structure and amino acid sequence of a peptide dictate the antioxidant action. The TSNTF peptide is neutrally charged with $20 \%$ hydrophobicity (Fig. S3), whereas it contains three hydroxylated residues, two threonines and one serine, in addition to the phenolic phenylalanine and carboxylic aspartic acid. These amino acids are reported to play a critical role in radical scavenging because of the nucleophilic nature of their side chains (Zou et al. 2016). Particularly, the side chain of serine contains a primary hydroxyl group while in threonine is a secondary hydroxyl group which are preferentially proton transferring groups (Li et al. 2018). Serine and threonine residues in peptides have also been shown to directly interact with free radicals (Agrawal et al. 2019). Serine and threonine residues were also found able to form hydrogen bonds with DPPH radical and possess cyto-protective function by elevating the intracellular antioxidant factors such nuclear factor erythroid 2-related factor, Nrf2, and nitric oxide, NO (Maralani et al. 2012).

In mice, serine supplementation attenuated the effects of oxidative stress induced by treatment with diquat, a bipyridyl herbicide which generates ROS, by supporting GSH synthesis (Zhou et al. 2017). In the same experiment, mouse hepatocytes were cultured with diquat and Ser, Ser effects on oxidative stress are mediated by its promotion of cystathionine $\beta$-synthase (CBS) activity which is utilized to synthesize GSH. This function gives Ser a role in promoting the entry of homocysteine into the transsulfuration pathway to enhance GSH production Additionally, in mice, Ser supplementation helped reduce oxidative stress and steatosis induced by feeding a high-fat diet through epigenetically modulating the abundance of genes for GSH synthesis to promote synthesis and reduce ROS (Zhou et al. 2018). In fish fed optimal amounts of threonine showed increased plasma antioxidant enzymes, superoxide dismutase (SOD), glutathione peroxidase (GPX) and catalase (CAT) (Habte-Tsion et al. 2016). These observations solidify the link between the sequence and the ex vivo antioxidant action of honey TSNTF peptide found in this study. It argues that the peptide TSNTF, containing a Ser residue and 2 Thr residues, could interact with ROS resulting in less depletion of GSH, and likely promoting GSH synthesis as well as induction of the intracellular antioxidant response enzymes (Fernandes et al. 2007).

\section{Conclusion}

The findings of this study highlight that honey proteins have anti-oxidant activity and possess a potent antioxidant pentapeptide, TSNTF. The TSNTF peptide was the major peptide in the most potent antioxidant farctions, P3 and P4 that demonstrated to be potent scavenger of superoxide radical and DPPH radical. The protective role of TSNTF peptide fraction on cell viability and antioxidant defenses of human HCT-116 cells challenged by hydrogen peroxide and diethyl maleate was demonstrated. This study is, thus, the first to report such activity by honey MRJP1 and a derived peptide. Peptic hydrolysates of honey proteins offer great promises for their potential applications in nutraceutical industry. The ex vivo antioxidant action of TSNTF peptide, able to protect human and yeast cells against oxidative damage, suggest its excellent candidacy as new bioactive peptide and a promising therapeutic peptide against oxidative stress related diseases. 


\section{Supplementary Information}

The online version contains supplementary material available at https://doi. org/10.1186/s43014-021-00052-2

Additional file 1: Fig. S1. Fluorescent image of control HCT-116 cells loaded with DCFH-DA but not oxidized or any peptides were added.

Additional file 2: Fig. S2. MALDI-TOF/MS spectra of peptide fractions P3 (A) and P4 (B) obtained from Sephacryl S-100 column. The sequences of peptides were identified by subjecting the major precursor ions in each fraction to MS/MS analysis, using automated application to MASCOT and SEQUEST database.

Additional file 3: Fig. S3. Amino acid sequence of the Major Royal Jelly Protein 1 (MRJP1) of honey, depicting peptides (bold, underlines) found in the active fractions (A). Table B depicting the sequence, parent protein and characteristics of peptides. Peptide characteristics were estimated using Peptide-2 server (https://www.peptide2.com/N_peptide_ hydrophobicity_hydrophilicity.php).

\section{Abbreviations}

THP: Total honey proteins; HP-pn: Honey proteins digested with pepsin at pH(n); HP-pn-a: HP-pn digested by a-chymotrypsin; HP-pn-T: HP-pn digested by trypsin; HP-pn-a/T: HP-pn digested by both a-chymotrypsin and trypsin; DPPH: 2,2-Diphenyl-1-picrylhydrazyl; DEM: Diethyl maleate; MALDI-TOF/ MS: Matrix-assisted laser desorption ionization-time-of-flight mass spectrometry

\section{Acknowledgements}

Not applicable.

\section{Authors' contributions}

Hisham R. Ibrahim - Conceptualization, Investigation, Supervision, Writing and Editing the manuscript. Fukiko Nanbu - Formal analysis, Data Visualization. Takeshi Miyata - Methodology, Review the manuscript. The author(s) read and approved the final manuscript.

\section{Funding}

Funding information is not applicable. No funding was received.

\section{Availability of data and materials}

All data generated or analyzed during this study are included in this published article (and its supplementary material files).

\section{Ethics approval and consent to participate}

Not applicable. The article does not include animal or human experiments.

\section{Consent for publication}

Neither the article nor portions of it have been previously published elsewhere.

The manuscript is not under consideration for publication in another journal, and will not be submitted elsewhere until the journal Food Production, Processing and Nutrition (FPPN) editorial process is completed. All authors consent to the publication of the manuscript in FPPN, should the article be accepted by the Editor-in-chief upon completion of the refereeing process.

\section{Competing interests}

The authors have no competing interest directly relevant to the content of this article.

Received: 2 September 2020 Accepted: 18 January 2021

Published online: 08 March 2021

\section{References}

Agrawal, H., Joshi, R., \& Gupta, M. (2019). Purification, identification and characterization of two novel antioxidant peptides from finger millet (Eleusine coracana) protein hydrolysate. Food Research International, 120, 697-707

Ahmed, S., Sulaiman, S. A., Baig, A. A., Ibrahim, M., Liagat, S., Fatima, S., .. Othman, N. H. (2018). Honey as a potential natural antioxidant medicine: An insight into its molecular mechanisms of action. Oxidative Medicine and Cellular Longevity, 2018, 8367846.

Ahmed, S. A., El-Bassiony, T., Elmalt, L. M., \& Ibrahim, H. R. (2015). Identification of potent antioxidant bioactive peptides from goat milk proteins. Food Research International, 74, 80-88.

Albert, S., Bhattacharya, D., Klaudiny, J., Schmitzová, J., \& Simúth, J. (1999). The family of major royal jelly proteins and its evolution. Journal of Molecular Evolution, 49, 290-297.

Almasaudi, S. B., Abbas, A. T., Al-Hindi, R. R., El-Shitany, N. A., Abdel-Dayem, U. A., Ali, S. S., ... Harakeh, S. M. (2017). Manuka honey exerts antioxidant and antiinflammatory activities that promote healing of acetic acid-induced gastric ulcer in rats. Evidence-based Complementary and Alternative Medicine, 2017, 5413917.

Brudzynski, K., \& Maldonado-Alvarez, L. (2018). Identification of Ubiquinones in honey: A new view on their potential contribution to honey's antioxidant state. Molecules, 23(12), 3067.

Chua, L. S., Lee, J. Y., \& Chan, G. F. (2013). Honey protein extraction and determination by mass spectrometry. Analytical and Bioanalytical Chemistry, 405, 3063-3074.

Chua, L. S., Lee, J. Y., \& Chan, G. F. (2015). Characterization of the proteins in honey. Analytical Letters, 48, 697-709.

Combarros-Fuertes, P., Estevinho, L. M., Dias, L. G., Castro, J. M., Tomas-Barberan, F. A., Tornadijo, M. E., \& Fresno-Baro, J. M. (2019). Bioactive components, antioxidant and antibacterial activities of different varieties of honey: A screening prior to clinical application. Journal of Agricultural and Food Chemistry, 67, 688-698.

Di Girolamo, F., D'Amato, A., \& Righetti, P. G. (2012). Assessment of the floral origin of honey via proteomic tools. Journal of Proteomics, 75, 3688-3693.

Fernandes, P. N., Mannarino, S. C., Silva, C. G., Pereira, M. D., Panek, A. D., \& Eleutherio, E. C. (2007). Oxidative stress response in eukaryotes: Effect of glutathione, superoxide dismutase and catalase on adaptation to peroxide and menadione stresses in Saccharomyces cerevisiae. Redox Report : Communications in Free Radical Research, 12, 236-244

Geter, D. R., Zhang, F., Schisler, M. R., Wood, A. J., Kan, H. L., Jeong, Y. C., ... Gollapudi, B. B. (2012). Genetic damage, but limited evidence of oxidative stress markers in diethyl maleate-induced glutathione depleted mouse lymphoma L5178Y (TK(+/-)) cell cultures. Toxicology Mechanisms and Methods, 22, 547-554

Habte-Tsion, H.-M., Ren, M., Liu, B., Ge, X., Xie, J., \& Chen, R. (2016). Threonine modulates immune response, antioxidant status and gene expressions of antioxidant enzymes and antioxidant-immune-cytokine-related signaling molecules in juvenile blunt snout bream (Megalobrama amblycephala). Fish \& Shellfish Immunology, 51, 189-199.

Hofstee, B. H. J. (1965). The rate of chymotrypsin autolysis. Archives of Biochemistry and Biophysics, 112, 224-232.

Ibrahim, H. R., Isono, H., \& Miyata, T. (2018). Potential antioxidant bioactive peptides from camel milk proteins. Animal Nutrition, 4, 273-280.

Jerkovic, I., Tuberoso, C. I., Marijanovic, Z., Kranjac, M., \& Malenica-Staver, M. (2015). Antioxidant capacity and chemical profiles of Satureja montana L. Honey: hotrienol and syringyl derivatives as biomarkers. Chemistry \& Biodiversity, 12 , 1047-1056.

Kumar, S., \& Hein, G. E. (1970). Mechanism of autolysis of a-chymotrypsin. Biochemistry, 9, 291-297.

Kumul, R. C., Ruiz, J. C. R., Vazquez, E. O., \& Campos, M. R. S. (2015). Antioxidant potential of melipona beecheii honey and its relationship to health: A review. Nutrición Hospitalaria, 32, 1432-1442.

Laemmli, U. K. (1970). Cleavage of structural proteins during the assembly of the head of bacteriophage T4. Nature, 227, 680-685.

Li, Y., Toscano, M., Mazzone, G., \& Russo, N. (2018). Antioxidant properties and free radical scavenging mechanisms of cyclocurcumin. New Journal of Chemistry, 42, 12698-12705.

Maralani, M. N., Movahedian, A., \& Javanmard, S. H. (2012). Antioxidant and cytoprotective effects of L-Serine on human endothelial cells. Research in Pharmaceutical Sciences, 7, 209-215.

Masalha, M., Abu-Lafi, S., Abu-Farich, B., Rayan, M., Issa, N., Zeidan, M., \& Rayan, A. (2018). A new approach for indexing honey for its heath/medicinal benefits: Visualization of the concept by indexing based on antioxidant and antibacterial activities. Medicines (Basel), 5, 135.

Nooh, H. Z., \& Nour-Eldien, N. M. (2016). The dual anti-inflammatory and antioxidant activities of natural honey promote cell proliferation and neural regeneration in a rat model of colitis. Acta Histochemica, 118, 588-595. 
Ramanathan, A. N. K. G., Nair, A. J., \& Sugunan, V. S. (2018). A review on Royal Jelly proteins and peptides. Journal of Functional Foods, 44, 255-264.

Shenoy, V. P., Ballal, M., Shivananda, P., \& Bairy, I. (2012). Honey as an antimicrobial agent against pseudomonas aeruginosa isolated from infected wounds. Journal of Global Infectious Diseases, 4, 102-105.

Teobaldi, I., Stoico, V., Perrone, F., Bruti, M., Bonora, E., \& Mantovani, A. (2018). Honey dressing on a leg ulcer with tendon exposure in a patient with type 2 diabetes. Endocrinology, Diabetes \& Metabolism Case Reports, 2018, 18-0117.

Won, S. R., Lee, D. C., Ko, S. H., Kim, J. W., \& Rhee, H. I. (2008). Honey major protein characterization and its application to adulteration detection. Food Research International, 41, 952-956.

Zhou, X., He, L., Wu, C., Zhang, Y., Wu, X., \& Yin, Y. (2017). Serine alleviates oxidative stress via supporting glutathione synthesis and methionine cycle in mice. Molecular Nutrition \& Food Research, 61, 1700262.

Zhou, X., He, L., Zuo, S., Zhang, Y., Wan, D., Long, C., ... Yin, Y. (2018). Serine prevented high-fat diet-induced oxidative stress by activating AMPK and epigenetically modulating the expression of glutathione synthesis-related genes. Biochimica et Biophysica Acta, Molecular Basis of Disease, 1864, 488-498.

Zou, T. B., He, T. P., Li, H. B., Tang, H. W., \& Xia, E. Q. (2016). The structure-activity relationship of the antioxidant peptides from natural proteins. Molecules, $21,72$.

\section{Publisher's Note}

Springer Nature remains neutral with regard to jurisdictional claims in published maps and institutional affiliations.

Ready to submit your research? Choose BMC and benefit from:

- fast, convenient online submission

- thorough peer review by experienced researchers in your field

- rapid publication on acceptance

- support for research data, including large and complex data types

- gold Open Access which fosters wider collaboration and increased citations

- maximum visibility for your research: over $100 \mathrm{M}$ website views per year

At $\mathrm{BMC}$, research is always in progress.

Learn more biomedcentral.com/submissions 